\title{
Changes in the activity of rat muscle AMP deaminase in relation to the proportion of dietary protein
}

\author{
By L. V. TURNER AND E. B. FERN \\ Clinical Nutrition and Metabolism Unit, Human Nutrition Department, London School \\ of Hygiene and Tropical Medicine, Keppel Street, London $W_{1} E_{7} H T$
}

(Received I 8 Fanuary r974-Accepted 4 March 1974)

\begin{abstract}
1. The purine nucleotide cycle has been proposed (Lowenstein, 1972) as an alternative scheme for amino acid deamination in tissues, such as skeletal muscle, having low concentrations of glutamate dehydrogenase (EC I . 4. I .2).

2. Activities of AMP deaminase $(E C 3.5 \cdot 4.6)$, one of the enzymes of the cycle, have been measured in soleus, plantaris and extensor digitorum longus muscles of rats maintained for I $8 \mathrm{~d}$ on diets providing $0,0.035$ or 0. I o net dietary protein energy (energy supplied by utilizable protein: total metabolizable energy, NDp:E), and in rats given the O.rO NDp: $\mathrm{E}$ diet for $3 \mathrm{~d}$ after the o or $0.035 \mathrm{NDP}: \mathrm{E}$ regimens.

3. Concentration of AMP deaminase in the different muscles from the control ( $0 \cdot 10 \mathrm{NDP}: \mathrm{E}$ diet) rats appeared to bear an inverse relationship to the proportion of mitochondria-rich fibres (i.e. rich in glutamate dehydrogenase) in each muscle.

4. Dietary protein deprivation ( 0 or $0.035 \mathrm{NDp}: \mathrm{E}$ ) led to adaptive reductions in AMPdeaminase activity in the soleus and plantaris muscles, but in the extensor muscle the 0.035 NDp: $\mathrm{E}$ diet produced no change, while the $O$ NDp: $\mathrm{E}$ diet caused an increase in activity.

5. Refeeding the 0 IO NDP:E diet to the protein-deprived rats caused reductions of AMPdeaminase activity to lower levels in all three muscles, except in the instance of soleus in rats refed after the $0.035 \mathrm{NPp}: \mathrm{E}$ diet.

6. In view of the different responses shown by the three muscles to the dietary treatments, the importance of specifying the particular muscles used in future nutritional studies is emphasized.

7. The adaptive changes in AMP deaminase are discussed in terms of operation of the purine nucleotide cycle for amino acid deamination responding to the changes in amino acid catabolism known to be caused in muscle by these protein-deficient diets.
\end{abstract}

The currently accepted scheme for the deamination of amino acids involves the transfer of amino groups from the various amino acids to $\alpha$-ketoglutarate, thus forming glutamic acid, which is then oxidatively deaminated by glutamate dehydrogenase $(E C$ I.4.r.2) (Braunstein, 1957). In skeletal muscle the activity of glutamate dehydrogenase is relatively low (Wergedal \& Harper, 1964; Lowenstein, 1972), even though very high activities of the various transaminases are found (see Young, I970). Recently an alternative scheme for amino acid deamination has been proposed (Lowenstein, I972) in which a 'purine nucleotide cycle', catalysed by the sequential activity of the enzymes adenylosuccinate synthetase $(E C$ 6.3.4.4), adenylosuccinate lyase $(E C$ $4 \cdot 3 \cdot 2.2)$, and AMP deaminase $(E C \quad 3 \cdot 5 \cdot 4 \cdot 6)$, brings about the deamination of aspartic acid. Using skeletal muscle extracts, operation of the cycle has been demonstrated in vitro (Tornheim \& Lowenstein, 1972) and appears to be kinetically linked to glycolytic activity (Tornheim \& Lowenstein, I973). An inverse relationship has been demonstrated between the activities of glutamate dehydrogenase and AMP deaminase for a number of different rat tissues (Lowenstein, 1972), and it has long been known that in skeletal muscle, the richest source of AMP deaminase (Conway \& Cooke, 
I939), most of the ammonia present in the tissue is derived from this deaminase reaction (Lohmann, I93 1 ; Kalckar \& Rittenberg, I947).

In addition to its more obvious contractile role, skeletal muscle is largely responsible for the oxidation of the branched-chain amino acids (Sketcher, Fern \& James, I974) and also serves as an adaptive store of labile protein, supplying amino acids and glucogenic precursors to the blood in times of dietary insufficiency (Cahill, 1971). As a consequence, variations in the demand for amino acid deamination in muscle may be expected as a response to a change in nutritional status. Indeed, metabolic adaptation of glutamate dehydrogenase (Wergedal \& Harper, 1964) and of a number of aminotransferases (Ashley \& Fisher, 1967; Yamaguchi \& Kandatsu, 1967; Mimura, Yamada \& Swendseid, I968; Reeds, I974; Sketcher et al. I974) have been reported following changes in the proportion of protein in the diet. In view of the possible involvement in muscle protein metabolism of the enzymes catalysing the purine nucleotide cycle, we thought it of interest to investigate the effect of dietary protein content on the activity of one of the enzymes of the cycle, AMP deaminase. Since muscles differ in the proportions of their constituent fibre types (Close, 1972) and since AMP deaminase activity appears to differ in concentration in different muscles, being highest in those muscles containing predominantly glycolytic fibres (Raggi, Ronca-Testoni \& Ronca, r969; Turner \& Manchester, 1972) we have made our measurements on three distinct muscles of the rat hind-limb that differ characteristically in their fibre proportions (Edgerton, Gerchmann \& Carrow, 1969; Edgerton, quoted by Close, 1972).

\section{EXPERIMENTAL}

\section{Materials}

2-( $N$-2-hydroxyethylpiperazin- $N$ '-yl)ethanesulphonic acid (HEPES), 'A' grade, was obtained from Calbiochem, Los Angeles, California, USA. Adenosine 5 '-phosphate was obtained from Boehringer Corp. (London) Ltd, London $\mathrm{W}_{5} 2 \mathrm{TZ}$. Diet constituents were obtained from the following sources: Casumen (sodium caseinate), C. \& C. Prideaux, c/o Unigate Foods, Wincanton, Somerset; maize starch and dextrinized starch, C.P.C. (United Kingdom) Ltd, Trafford Park, Manchester MI 7 IPA; Solka Floc (cellulose), Johnsen, Jörgensen \& Wettre Ltd, London $\mathrm{EC}_{4}$; arachis oil, Croda Premier Oils Ltd, Stoneferry, Hull HU8 oBJ; and fat-soluble vitamin supplement, Cooper Nutritional Products Ltd, Stepfield, Witham, Essex. All other chemicals used were of analytical reagent grade obtained from BDH Chemicals Ltd, Poole, Dorset.

\section{Animals and diets}

Weanling female hooded rats, approximately $35^{-40} \mathrm{~g}$ in weight, were obtained from Animal Supplies (London) Ltd, London $\mathrm{NI}_{2}$ oDA. On arrival they were divided randomly into eight groups and housed three to a cage. All groups received initially ad lib. a powdered diet of $0 \cdot$ Io net dietary protein energy (energy supplied by utilizable protein:total metabolizable energy, NDp:E) containing the following constituents (g/kg): maize starch, 426; dextrinized starch, 272; Solka Floc, 9I; arachis oil, 45; mineral salt mixture, 45 ; ' $\mathrm{B}$ ' vitamin mixture, 10 ; fat-soluble vitamin supplement, 


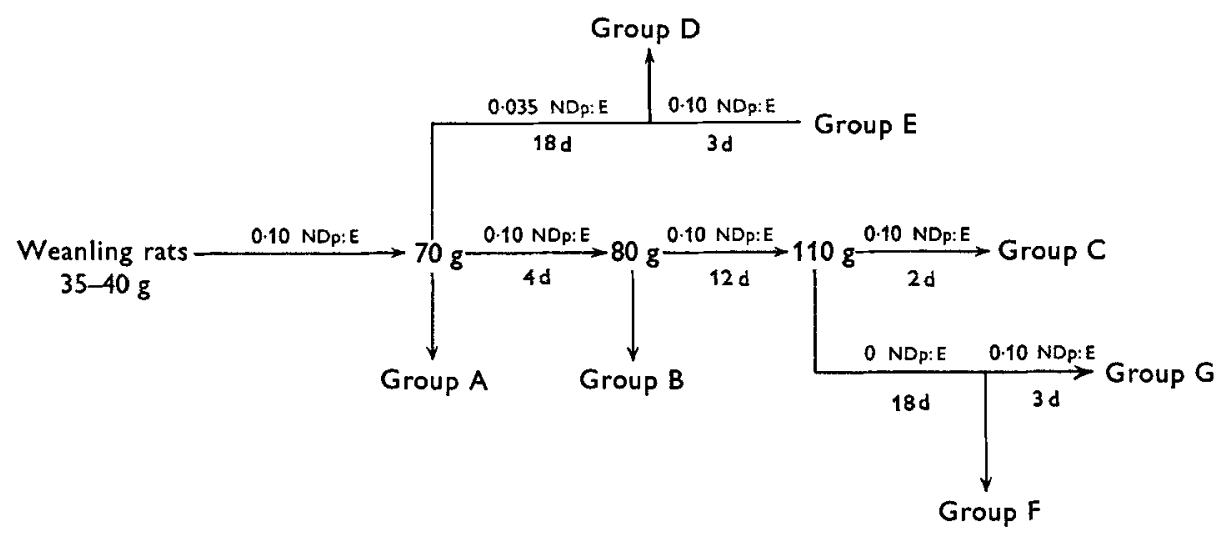

Fig. I. Diagrammatic representation of the feeding regimens for groups of rats given the $0 \cdot 10$, 0.035 and o net dietary protein energy (energy supplied by utilizable protein: total metabolizable energy, NDP:E) diets, showing body-weights of the rats and experimental feeding period for each diet.

I ; L-methionine, I; Casumen, rog. Details of the mineral salt mixture, the ' $B$ ' vitamin mixture, and the fat-soluble supplement are given by Payne \& Stewart (I972).

All rats had free access to this diet until the mean body-weight was approximately $7 \circ \mathrm{g}$. One group of rats was then killed (group A) to serve as ' $70 \mathrm{~g}$ weight controls', and two other groups were changed onto a $0.035 \mathrm{NDp}: \mathrm{E}$ diet, identical to the 0.10 NDP:E diet, except that the protein content was reduced by $65 \%$ and an equivalent quantity of maize starch was added. These two groups were maintained on the 0.035 NDp:E diet for $18 \mathrm{~d}$, at which time one group was killed (group D), whilst the other was given the $0.10 \mathrm{NDP}$ : $\mathrm{E}$ diet for a further $3 \mathrm{~d}$ before being killed (group E).

The remaining four groups continued to receive the O.IO NDP:E regimen; at $80 \mathrm{~g}$ body-weight, one group was killed to serve as ' $80 \mathrm{~g}$ weight controls' (group B), whilst the other groups were permitted to grow for a further $\mathbf{2} 2 \mathrm{~d}$ until their mean body-weight was $\mathrm{r}$ log. At this stage two of the remaining groups were given a protein-free isoenergetic diet for $18 \mathrm{~d}$. One group was then killed (group F), whilst the other group was given the $O$ I I NDp: $\mathrm{E}$ diet for a further $3 \mathrm{~d}$ (group G). The last group of rats given the $O \cdot Y O N D P: E$ diet served as age controls (group C) for the rats receiving the lowprotein diet. Fig. I presents in diagrammatic form the dietary treatment of the groups of rats.

\section{Determination of AMP deaminase activity}

Each measurement was done on extracts prepared from both homologous muscles of each rat. Rats were killed by decapitation and the soleus, plantaris and extensor digitorum longus (EDL) muscles of each leg rapidly dissected out. Each pair of muscles was weighed on a torsion balance and then homogenized with a 'Polytron' homogenizer (Kinematica GmbH, Lucerne, Switzerland) in $\mathbf{r} \cdot 8 \mathrm{ml}$ ice-cold extraction buffer containing $(\mathrm{mmol} / \mathrm{l})$ : $20 \mathrm{HEPES}, 800 \mathrm{KCl}$ and 30 potassium phosphate, adjusted to $\mathrm{pH} 6.90$ with $\mathrm{KOH}$. The inclusion of the phosphate was to take advantage of the effect of this anion in dissociating AMP deaminase from myofibrils (Currie \& 
Webster, I962). The homogenates were allowed to stand on ice for at least $\mathrm{I} \mathrm{h}$ to ensure effective solubilization of the enzyme, and then centrifuged at $30000 \mathrm{~g}$ for $30 \mathrm{~min}$ at $4^{\circ}$. Enzyme activity in the high-speed supernatant fraction was measured by following IMP production at $285 \mathrm{~nm}$ with a Gilford spectrophotometer fitted with constant-temperature cell housing and accessory chart recorder. The assays, performed in duplicate, were made at $25^{\circ}$ by adding $5 \circ \mu \mathrm{l}$ of the supernatant fraction to $2.0 \mathrm{ml}$ assay mixture containing (mmol/1): $20 \mathrm{HEPES}, 100 \mathrm{KCl}$ and $2 \mathrm{AMP}$, adjusted to $\mathrm{pH} 6.90$ with KOH. Preliminary measurements established that for all three muscle extracts the extinction changes observed were proportional to the quantity of extract added, and that when extracts from different muscles were mixed in different proportions, the activity measured was the sum of the individual activities. No significant differences were found between the $k_{m}$ values with respect to AMP concentration for extracts from the different muscles, the values being essentially identical to that reported for the purified enzyme when assayed in the presence of $100 \mathrm{mM}-\mathrm{KCl}$ (Ronca, Raggi \& Ronca-Testoni, 1968). Enzyme activities calculated from the linear increase in extinction at $285 \mathrm{~nm}\left(\Delta E_{\mathrm{mM}}^{10 \mathrm{~mm}}=0.23\right.$, Ronca et al. I968) are expressed as $\mu \mathrm{mol} /$ min per $g$ wet weight of tissue, at $25^{\circ}$ and $\mathrm{pH} 6 \cdot 9$.

\section{Statistical treatment of results}

The duplicate enzyme activity measurements determined for each muscle extract were averaged, and the mean and standard error of the mean calculated for each group of rats. Table 2 presents the values so obtained and shows the number of rats in each group. Statistical significance, indicated if $P<0.05$, was assessed by Student's $t$ test.

\section{RESULTS}

The effects of the different feeding regimens on the mean body-weights, and on the fresh weights of the three individual muscles dissected from the hind-limb, are presented in Table I. For simplicity only the mean values have been given; in each instance the standard error of the mean fell within $5 \%$ of the mean value. The control rats given the high-protein ( $\mathrm{O} \cdot \mathrm{IO} \mathrm{NDp}: \mathrm{E}$ ) diet (groups A, B and C) from weaning grew at a rate of $2.7 \mathrm{~g} / \mathrm{d}$, the maximal rate for pre-adult rats of this rather slow-growing strain. In rats given this diet, the individual muscles all increased in weight by roughly the same proportion; at the end of the $\mathrm{r} 8 \mathrm{~d}$ experimental feeding period, muscle masses in rats of group $\mathrm{C}$ were some $60-70 \%$ greater than those of group $\mathrm{A}$.

The rats given the low-protein (0.035 NDp:E) diet for a corresponding period (group D) did not grow. In fact, a very slight loss of body-weight $(0.2 \mathrm{~g} / \mathrm{d})$ was recorded. However, the muscle fresh weights for this group did not differ significantly from those of the appropriate group of weight controls, group A. On returning to the highprotein diet (group E), these protein-deprived rats resumed growth, the body mass increasing by $30 \%$ within $3 \mathrm{~d}$. All three hind-limb muscles showed weight gains during this refeeding period, but whilst the percentage increase in mass of the soleus was more or less comparable to that of total body-weight, the increases for plantaris and EDL muscle were smaller, being only some $14-15 \%$. 
Table $\mathrm{x}$. The effect of feeding diets with different net protein energy contents (energy supplied by utilizable protein: total metabolizable energy, NDp:E) on the mean body-weight $(\mathrm{g})$ and the wet weights $(\mathrm{mg})$ of the three muscles from the hind-limb, soleus, plantaris and extensor digitorum longus (EDL) of the hooded rat

(Mean values; no. of animals in each group in parentheses)

\begin{tabular}{|c|c|c|c|c|c|}
\hline \multirow[b]{2}{*}{ Group } & \multirow[b]{2}{*}{ Dietary treatment* } & \multirow[b]{2}{*}{ Body-wt } & \multicolumn{3}{|c|}{ Muscle wt } \\
\hline & & & Soleus & Plantaris & EDL \\
\hline A & $\begin{array}{l}\text { Maintained on } 0.10 \text { NDp: } \mathrm{E} \text { diet from } \\
\text { weaning to } 70 \mathrm{~g} \text { body-wt }\end{array}$ & 69 & $28 \cdot \circ(6)$ & $52 \cdot 7(8)$ & $30 \cdot 0(7)$ \\
\hline B & $\begin{array}{l}\text { As group } A \text {, but maintained for } \\
\text { further } 4 \mathrm{~d} \text { on } 0.10 \text { NDp: } \mathrm{E} \text { diet until } \\
80 \mathrm{~g} \text { body-wt }\end{array}$ & 78 & $32 \cdot 2(5)$ & $57 \cdot 4(5)$ & $33 \cdot 4(5)$ \\
\hline $\mathrm{C}$ & $\begin{array}{l}\text { As group A, but maintained for } \\
\text { further I } 8 \mathrm{~d} \text { on } 0.10 \text { NDp: E diet } \\
\text { (age controls) }\end{array}$ & I 6 & $49 \cdot 2(5)$ & $98 \cdot 5(5)$ & $50 \cdot 2(5)$ \\
\hline D & $\begin{array}{l}\text { As group A, but maintained for } \\
\text { further } 8 \mathrm{~d} \text { on } 0.035 \mathrm{NDp}: \mathrm{E} \text { diet } \\
\text { (low-protein) }\end{array}$ & 64 & $25 \cdot 8(5)$ & $55 \cdot 9(5)$ & $29 \cdot 7(4)$ \\
\hline $\mathrm{E}$ & $\begin{array}{l}\text { As group } \mathrm{D} \text {, then given } 0.10 \mathrm{NDp}: \mathrm{E} \\
\text { diet for } 3 \mathrm{~d} \text { (low-protein, refed) }\end{array}$ & 83 & $32 \cdot 2(7)$ & $63.5(8)$ & $34 \cdot 2(8)$ \\
\hline $\mathbf{F}$ & $\begin{array}{l}\text { Maintained on } 0 \cdot \text { I o NDp: } \mathrm{E} \text { diet until } \\
\text { I I } \mathrm{g} \text { body-wt, then given } 0 \text { NDp: } \mathrm{E} \\
\text { diet for } \mathrm{I} 8 \mathrm{~d} \text { (protein-free) }\end{array}$ & $8 I$ & $40 \cdot 6(5)$ & $79 \cdot 2(5)$ & $37.6(5)$ \\
\hline $\mathrm{G}$ & $\begin{array}{l}\text { As group } F \text {, then given } O \cdot 10 \text { NDp: } E \\
\text { diet for } 3 \mathrm{~d} \text { (protein-free, refed) }\end{array}$ & 100 & $42 \cdot 7(5)$ & $80 \cdot 6(5)$ & $43^{\cdot 6(5)}$ \\
\hline
\end{tabular}

* For details see p. 540 .

Since total dietary protein deprivation leads to loss of body-weight, the effect of the protein-free diet (O NDP:E) was investigated in a group of rats maintained on the high-protein diet until they had reached a mean body-weight of $\mathrm{I}$ Io $\mathrm{g}$, before being presented with the protein-free diet. Initial body- and muscle weights of this group were thus comparable to those of group $\mathrm{C}$, whilst at the end of the $\mathrm{I} 8 \mathrm{~d}$ period, mean body-weights were similar to those of control group B. Interestingly, muscle weights of rats given this protein-free diet did not decrease in proportion to the loss of total body-weight. Presumably the relative sparing of these particular muscles reflects the importance to the animal of their function in postural maintenance and locomotion. A $3 \mathrm{~d}$ refeeding period with the high-protein diet resulted in a $25 \%$ increase in bodyweight (group G) in these protein-deprived rats. The percentage increase in mass of the EDL muscle was similar to that found in the low-protein, refed group, but for soleus and plantaris muscles only marginal (2-5\%) increases in mass were found in the $3 \mathrm{~d}$ period.

Table 2 presents the activities of AMP deaminase, expressed per $g$ fresh weight, for the three hind-limb muscles from rats of the different dietary groups. Although the relative activities found for the three muscles were comparable to previously reported values (Raggi et al. 1969; Turner \& Manchester, 1972) the absolute activities were six-eight times greater. Differences in the extraction media and assay procedures for 
Table 2. The effect of feeding diets with different net protein energy contents (energy supplied by utilizable protein:total metabolizable energy, NDP:E) on AMP deaminase

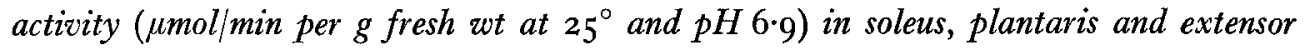
digitorum longus (EDL) muscles of the hooded rat

(Mean values with their standard errors; no. of animals in each group in parentheses)

\begin{tabular}{|c|c|c|c|c|c|c|c|}
\hline \multirow[b]{3}{*}{ Group } & \multirow[b]{3}{*}{ Dietary treatment $\dagger$} & \multirow{3}{*}{$\begin{array}{l}\text { Statistical } \\
\text { comparison } \\
\text { with group }\end{array}$} & \multicolumn{5}{|c|}{ AMP deaminase activity } \\
\hline & & & \multicolumn{2}{|c|}{ Soleus } & \multicolumn{2}{|c|}{ Plantaris } & EDL \\
\hline & & & Mean & SE & Mean & $\mathrm{SE}$ & Mean \\
\hline A & $\begin{array}{l}\text { Maintained on o. Io NDp: } \mathrm{E} \text { diet } \\
\text { from weaning to } 70 \mathrm{~g} \text { body-wt }\end{array}$ & - & 244 & I4 (6) & 605 & I7 (8) & $426 \quad 16(7)$ \\
\hline $\mathrm{B}$ & $\begin{array}{l}\text { As group } A \text {, but maintained on } \\
0.10 \text { NDp: } E \text { diet for further } \\
4 \mathrm{~d} \text { to } 80 \mathrm{~g} \text { body-wt }\end{array}$ & - & 265 & I6 (5) & 652 & $9(5)$ & $436 \quad 25(5)$ \\
\hline $\mathrm{C}$ & $\begin{array}{l}\text { As group A, but maintained for } \\
\text { further } 18 \mathrm{~d} \text { on } 0.10 \mathrm{NDp}: \mathrm{E} \\
\text { diet (age controls) }\end{array}$ & A & 249 & I9 (5) & ${ }^{689}$ & $29(5)$ & $490 \quad 29(5)$ \\
\hline $\mathrm{D}$ & $\begin{array}{l}\text { As group } A \text {, but maintained for } \\
\text { further } 18 \mathrm{~d} \text { on } 0.035 \text { NDP:E } \\
\text { diet (low-protein) }\end{array}$ & $\begin{array}{l}\text { A } \\
\text { C }\end{array}$ & $\begin{array}{r}\text { I6I } \\
\text { *** }\end{array}$ & I0 (5) & 529 & $34(5)$ & $440 \quad 18(4)$ \\
\hline E & $\begin{array}{l}\text { As group D, then given } 0.10 \\
\text { NDp: } \mathrm{E} \text { diet for } 3 \mathrm{~d} \text { (low- } \\
\text { protein, refed) }\end{array}$ & $\mathrm{D}$ & I $93_{*}$ & $8(7)$ & 502 & $17(8)$ & $345_{* * *} 7(8)$ \\
\hline $\mathbf{F}$ & $\begin{array}{l}\text { Maintained on } 0.1 \circ \mathrm{NDp}: \mathrm{E} \text { diet } \\
\text { until I I } \mathrm{g} \text { body-wt then } \\
\text { O NDp: } \mathrm{E}\end{array}$ & $\begin{array}{l}\mathrm{B} \\
\mathrm{C}\end{array}$ & $223_{*}$ & $8(5)$ & 642 & $36(5)$ & $537_{*} 34(5)$ \\
\hline G & $\begin{array}{l}\text { As group } F \text { then given } 0.10 \\
\text { NDp: } \mathrm{E} \text { diet for } 3 \mathrm{~d} \text { (protein- } \\
\text { free, refed) }\end{array}$ & $\mathbf{F}$ & I68 & $8(5)$ & 520 & $21(5)$ & $335_{* * *} 23(5)$ \\
\hline
\end{tabular}

Difference between mean values statistically significant: ${ }^{*} P<0.05$; ** $P<0.01$; *** $P<0.001$. $\uparrow$ For details see p. 540 .

muscle extracts from the hooded rats failed to account for these higher values. However, strain differences between the types of rat used could afford an explanation. Glutamate dehydrogenase activity in hemidiaphragms from hooded rats was found to be three times higher ('Turner unpublished results) than the activity reported for an albino strain (Turner \& Manchester, 1972), suggesting that amino acid deamination may be relatively more important to muscle protein metabolism in the hooded rats. It is important to remember, however, that muscle AMP deaminase probably exists in vivo in at least a partially inhibited state, the degree of inhibition depending upon the ratio, nucleoside triphosphates:nucleoside diphosphates (Ronca et al. 1968) so that the 6to 8-fold higher activity found in this study need not imply activity of the same magnitude in vivo.

In the control rats maintained on the high-protein diet, the total content of AMP deaminase/muscle more or less doubled during the $18 \mathrm{~d}$ feeding period (comparison of groups $\mathrm{A}$ and $\mathrm{C}$ ). In the plantaris and EDL muscles the increase in total activity was relatively greater than the increase in muscle mass so that an increase in specific 
activity/g was recorded. In soleus, however, enzyme activity/unit mass was unchanged by the high-protein feeding regimen.

Dietary protein restriction, as in the rats given the low-protein diet (group D) resulted in significantly decreased activity/unit mass in both soleus and plantaris muscles, but had no effect on the activity in EDL muscle. On refeeding the highprotein diet, total contents of enzyme activity in the plantaris and EDL muscles remained effectively unchanged, but since for each muscle the mass was increased by some $15 \%$, AMP deaminase activity/g was reduced. By contrast, an increase in total activity was found for the soleus muscle, and although muscle mass increased by $25 \%$ during the $3 \mathrm{~d}$ period, an enhancement of deaminase activity/unit mass was still observed.

The rats given the protein-free diet demonstrated a different response. In all three muscles, total enzyme activity was reduced, but because of the changes in mass of the individual muscles, the deaminase activity/unit weight was significantly reduced in soleus, but increased in the EDL muscle. Mean activity/g in plantaris was reduced, but the difference from group $\mathrm{C}$ was not statistically significant. Refeeding the highprotein diet caused a further fall in total AMP deaminase activity in each muscle, and was manifest in each instance as a statistically significant decrease in enzyme activity/unit muscle mass.

\section{DISCUSSION}

Although most amino acids are deaminated in the liver, it is now recognized that skeletal muscle acts as the major site for the degradation of the branched-chain amino acids (Reeds, 1974; Sketcher et al. 1974). Adaptive changes in some of the enzymes involved in the catabolism of these amino acids have been shown to occur in dietary protein insufficiency (Reeds, I974; Sketcher et al. 1974). Thus, the enhanced activity of the branched-chain aminotransferases (Mimura et al. 1968) and of aspartate aminotransferase ( $E C$ 2.6. I. I) (Yamaguchi \& Kandatsu, 1967) observed in dietary protein depletion would have the effect of facilitating the provision of aspartate prior to its entry into the purine nucleotide cycle. Accordingly, in this investigation we have looked for possible changes in AMP deaminase activity, considered as representative of the enzymes of the purine nucleotide cycle, under dietary conditions in which it was already established that adaptation of muscle enzymes to dietary protein content took place.

As well as involvement in the purine nucleotide cycle, it is possible that deamination of AMP may be of importance in the catabolism of the adenine nucleotides, either through changes in energy metabolism, or in the degradation of nucleic acids. In this study the different groups of rats were given isoenergetic diets, and were permitted to feed ad lib. Taskar \& Tulpule (1964) found no change in the total acid-soluble phosphates (including the adenine nucleotides) in muscle from rats given a protein-deficient diet, whereas Howarth \& Baldwin (I97I), investigating rats given a restricted diet, and also rats recovering from the restricted diet, found no change in the total adenine nucleotides in muscle. It would therefore seem unlikely that in the present investigation there would be a change in the pool size of adenine nucleotides. However, the 
possibility of an alteration in the rate of turnover of the nucleotide pool cannot be so easily eliminated.

Possible involvement of AMP deaminase in adenine nucleotide catabolism following nucleic acid breakdown is rather more difficult to dissociate from any effect on protein or amino acid metabolism. The rate of protein synthesis in skeletal muscle, measured in vivo, is linearly related to the concentration of RNA in the tissue (Howarth, r972; Millward, Garlick, James, Nnanyelugo \& Ryatt, r973). Protein deprivation, resulting in a fall in muscle protein synthesis, leads to a reduction in the RNA concentration. Whether this fall in RNA results from an enhanced rate of degradation, reduced rate of synthesis, or both, is still uncertain. Adaptation of AMP deaminase might be expected to occur if the rate of nucleic acid degradation was increased. Accordingly in this study the different groups of rats were given the different diets for $18 \mathrm{~d}$ to allow time for the RNA contents to reach new steady-state levels appropriate for the protein synthesis existing in the muscles as a consequence of the dietary treatments (Waterlow \& Stephen, 1968; Millward et al. 1973).

If AMP deaminase was involved in nucleic acid degradation, then one might reasonably expect a correlation between the activity of the enzyme and the concentration of the RNA. Of the three muscles investigated in this study, the soleus has the highest RNA content per unit weight, with the plantaris and EDL muscles having $65 \%$ and $56 \%$ respectively of this value (Goldberg, 1967 ). AMP deaminase activity, however, is lowest in the soleus, intermediate in the EDL muscle and highest in the plantaris. Furthermore, in preliminary studies we have found that in soleus, for example, the RNA concentration at the end of the $18 \mathrm{~d}$ dietary period had fallen to the same value whether the rats were given the low-protein or the zero-protein diet. By contrast, AMP deaminase activity was significantly different in these two dietary states.

Lowenstein (1972) has demonstrated that for a number of different rat tissues, the concentration of AMP deaminase activity bears an inverse relationship to glutamate dehydrogenase activity. In skeletal muscle, glutamate dehydrogenase is restricted exclusively to the mitochondria (Pette, 1966) and would therefore be expected in highest concentration in those muscles containing a high proportion of mitochondriarich fibres, e.g. soleus (Edgerton et al. 1969). Conversely, plantaris and EDL muscle contain a higher proportion of 'white' glycolytic fibres, $65 \%$ and $51 \%$ respectively (Edgerton et al. 1969; Edgerton, quoted by Close, 1972), and would therefore be expected to have correspondingly higher contents of AMP deaminase. It would appear therefore that the reciprocity between the activities of AMP deaminase and glutamate dehydrogenase extends even to different types of skeletal muscles, and it may be the situation that the postulated linkage between glycolysis and the activity of the purine nucleotide cycle has a compartmental basis.

The effect of a low-protein diet, sufficient only to maintain the weight of the animal, is to cause adaptive changes in the activity of muscle enzymes concerned with the catabolism of the branched-chain amino acids, resulting in the conservation of these amino acids (Sketcher $\boldsymbol{e t}$ al. 1974). Comparable dietary treatment resulted in reduction in the activity of AMP deaminase in soleus and plantaris, but had no effect in the EDL. In terms of activity of the purine nucleotide cycle, these adaptive decreases in 
deaminase activity are in accord with a reduced requirement for amino acid deamination, though the reason for the insensitivity of EDL muscle is not clear (see later discussion). Relatively smaller decreases in AMP deaminase activity were found in soleus and plantaris when feeding the protein-free diet. Such a response is in agreement with the results of Sketcher and co-workers (Sketcher et al. 1974; R. D. Sketcher \& W. P. T. James, unpublished results), who found that in vivo oxidation of leucine and valine in rats given a protein-free diet, although lower than controls receiving adequate dietary protein, was greater than that found in rats receiving the 0.035 NDP:E diet. Thus, greater conservation of the branched-chain amino acids in rats on the low-protein diet was associated with lower levels of AMP deaminase in soleus and plantaris than on the protein-free diet.

Paradoxically, the activity of AMP deaminase was found to increase in the EDL muscle of rats given the protein-free diet. Again, the reason for this response is not clear. A possible explanation may lie in the observation of Mimura et al. (1968) that in protein depletion the activity of the branched-chain aminotransferases increased by $100 \%$. By contrast, R. D. Sketcher \& W. P. T. James (personal communication) and Reeds (1974) found much more modest increases (5-24\%) under essentially identical dietary conditions. Unfortunately the Japanese workers do not state the type of skeletal muscle employed in their experiments. Sketcher and coworkers made their measurements on the entire gastrocnemius, which has a fibre composition essentially similar to that of plantaris (Sréter \& Woo, 1963), whilst Reeds apparently pooled extracts from thigh, diaphragm and abdominal wall muscles for his experiments. In view of the disparity between the results obtained by the different investigators, it seems a distinct possibility that different muscles respond differently to protein deprivation. Such a possibility would be in keeping with the findings reported in this present paper, and emphasizes the importance of making observations on distinct muscles of different fibre compositions.

The enhanced activity of AMP deaminase in the EDL suggests increased demand for amino acid deamination in this tissue during total protein deprivation. By comparison with soleus and plantaris, the EDL muscle in rats given the protein-free diet showed a relatively greater reduction in muscle wet mass, and since the different dietary treatments do not significantly alter the water contents of the muscles, this greater decrease in weight presumably reflects the greater lability of protein in this particular muscle (Fern, Broadbent $\&$ James, unpublished results). In addition, studies of the free amino acid concentrations have demonstrated that total protein deprivation leads to greater percentage reductions in free amino acid levels in the EDL muscle than in soleus (Fern, Broadbent \& James, unpublished results). Such findings would be in accord with a higher rate of amino acid deamination within this tissue.

On refeeding the O.IO NDP:E diet to the protein-depleted rats, 'catch-up' growth occurred, during which, according to Young, Stothers \& Vilaire (197I), the increase in muscle mass results not so much from an enhanced rate of total muscle protein synthesis, but rather from the depression to very low levels of the rate of protein degradation. Under such circumstances amino acid catabolism might be expected to be reduced as the tissue directs available amino acids to protein synthesis. With the 
exception of soleus in rats refed after the low-protein diet (see later), all three muscles showed significant reductions in AMP deaminase activity within $3 \mathrm{~d}$ of refeeding with the high-protein diet. For the plantaris and EDL muscles, it is remarkable how similar the AMP deaminase activities were during 'catch-up' growth after the different deficient diets, considering how disparate were the activities at the start of the refeeding period. For soleus, in rats refed after the 0.035 NDP:E diet, an increase in deaminase activity was found, though the level was still below that recorded at the termination of the protein-free diet. For this muscle the percentage increase in mass during the refeeding period was relatively greater than that for the other muscles, and may indicate restoration of normal levels of muscle amino acids within a very short period of time. Certainly by $5 \mathrm{~d}$ of refeeding the high-protein diet, essentially normal concentrations of free amino acids were found in soleus (Fern, Broadbent $\&$ James, unpublished results). It is entirely possible, therefore, that the increase in activity of AMP deaminase represents the return to normal levels of the enzyme in this muscle.

We wish to thank Professor J. C. Waterlow for his continued interest in this research. L.V.T. wishes to thank the Wellcome Trust for financial support.

\section{REFERENCES}

Ashley, J. H. \& Fisher, H. (1967). Br. F. Nutr. 21, 66ı.

Braunstein, A. E. (1957). Adv. Enzymol. 19, 335.

Cahill, G. F. (1971). In Muscle Metabolism in Exercise p. 103 [B. Pernow and B. Saltin, editors]. London: Plenum Press.

Close, R. I. (1972). Physiol. Rev. 52, 129.

Conway, E. J. \& Cooke, R. (1939). Biochem. F. 33, 479.

Currie, R. D. \& Webster, H. L. (I962). Biochim. biophys. Acta 64, 30.

Edgerton, V. R., Gerchmann, L. \& Carrow, R. ( I 969). Expl Neurol. 24, i Io.

Goldberg, A. L. (1967). Nature, Lond. 216, 1219.

Howarth, R. E. (1972). Can. F. Physiol. Pharmac. 50, 59.

Howarth, R. E. \& Baldwin, R. L. (197 I). F. Nutr. ror, 485.

Kalckar, H. M. \& Rittenberg, D. (1947). Y. biol. Chem. 170, 455.

Lohmann, K. (1931). Biochem. Z. 24I, 67.

Lowenstein, J. M. (r972). Physiol. Rev. 52, 382.

Millward, D. J., Garlick, P. J., James, W. P. T., Nnanyelugo, D. O. \& Ryatt, J. S. (1973). Nature, Lond. 24I, 204.

Mimura, T., Yamada, C. \& Swendseid, M. E. (I 968). F. Nutr. 95, 493.

Payne, P. R. \& Stewart, R. J. C. (1972). Lab. Anim. 6, 135.

Pette, D. (1966). In Symposium on Regulation of Metabolic Processes in Mitochondria: B.B.A. Library Vol. 7, p. 28. New York: Elsevier.

Raggi, A., Ronca-Testoni, S. \& Ronca, G. (1969). Biochim. biophys. Acta 178, 6 I9.

Reeds, P. J. (1974). Br. F. Nutr. 31, 259.

Ronca, G., Raggi, A. \& Ronca-Testoni, S. (1968). Biochim. biophys. Acta 167, 626.

Sketcher, R. D., Fern, E. B. \& James, W. P. T. (1974). Br. F. Nutr. 31, 333.

Sréter, F. A. \& Woo, G. (1963). Am. F. Physiol. 205, 1290.

Taskar, K. \& Tulpule, P. G. (1964). Biochem. $7.92,391$.

Tornheim, K. \& Lowenstein, J. M. (1972). F. biol. Chem. 247, 162.

Tornheim, K. \& Lowenstein, J. M. (1973). F. biol. Chem. 248, 2670.

Turner, L. V. \& Manchester, K. L. (1972). Biochem. F. 128, $80_{3}$.

Waterlow, J. C. \& Stephen, J. M. L. (1968). Clin. Sci. 35, 287.

Wergedal, J. E. \& Harper, A. E. (1964). Proc. Soc. exp. Biol. Med. r16, 600.

Yamaguchi, M. \& Kandatsu, M. (1967). Agric. biol. Chem. F. 31, 776.

Young, V. R. (1970). In Mammalian Protein Metabolism Vol. 4, p. 613 [H. N. Munro, editor]. London: Academic Press.

Young, V. R., Stothers, S. C. \& Vilaire, G. (1971). F. Nutr. ror, I379. 